\title{
Clinical Studies on the Urinary Excretion of Aldosterone in Myasthenia Gravis
}

\author{
Masato NAKAMOTO \\ The IInd Division of Medicine, Department of Medicine, Iwata Medical University, \\ Uchimaru, Morioka, Japan (Director : Professor Takeshi Kimura, M.D.)
}

Urinary excretion of aldosterone was measured (since 1963) by the modified method of Neher \& Wettstein, in 10 patients with myasthenia gravis including 2 cases of fulminant form, 4 cases of generalized form and 4 cases of ocular form.

The normal range of aldosterone values was 2.2 to $11.2 \mu \mathrm{g} /$ day (average: $5.5 \pm 2.2$ $\mu \mathrm{g} /$ day) in 8 healthy adults, and the total recovery was 55.0 to $59.3 \%$ (average: $57.7 \%$ ) with the addition of $30 \mu \mathrm{g}$ of d-aldosterone free in 900 c.c. of boiled urine, and the average value of paper blank was $0.025 \pm 0.002$.

A slight to moderate increase of urinary excretion of aldosterone was observed during the period "with" extremity weakness in 6 patients of fulminant form or generalized form, and then the value decreased to normal limits during the period "without" extremity weakness in 4 cases of 6 patients, whose muscle weakness was diminished by anti-cholinesterase therapy. In 4 cases of ocular form, however, aldosterone excretion was constantly within normal range.

The increase of sodium to potassium ratio in urine was also observed during the period "without" muscle weakness. No significant difference between both periods in the urinary excretion of 17-ketosteroids, 17-hydroxycorticosteroids and catecholamines was observed.

Transient hyperaldosteronuria, occuring during the period "with" extremity weakness in myasthenia gravis, might be explained by the following findings; 1) the abnormality in neuromuscular transmission with changes of intracellular electrolytes, wihch was considered to be one of the etiologic factors of myasthenia, 2) the occurence of clinically obvious muscle weakness with slight changes of mineralocortiocid activity, 3) the effectiveness of aldosterone antagonists and KCL tablets in this disease, notwithstanding normal electrolytes in serum, 4) the decrease of intracellular potassium caused by aldosterone, if potas-sium depletion was to occur in muscle tissue, 5) the inhibitory effect of aldosterone on acetylcholine in vitro.

The significance of the relation of the demonstrated hyperaldosteronuria, which may be secondary, in myasthenia gravis (of fulminant or generalized form), to the basic disorder in this desease is not yet apparent.

(pp. 770 784) 


\title{
重症筋無力症の尿中 Aldosterone 排泄量
}

\author{
に関する臨床的研究 \\ 岩手医科大学内科学第二講座（指導 木村武教授） \\ 仲本将人
}

(炤和 42 年 2 月 3 日受付)

緒 言

1955年 Conn ${ }^{1)}$ そより primary aldosteronism がはじめて提唱されて以来，筋麻痺ないしは筋無力状態 と電解質の問題, 特に intra- and extracellular のナトリウムおよびカリウムの変動との関係が重要視され

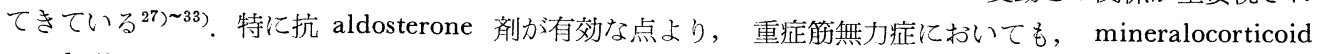
metabolism と密接な関係を有する aldosterone の果たす役割が問題となつている ${ }^{13}{ }^{14}$ ).

著者は1963年以来，重症筋無力症患者における筋無力症状におよぼす aldosterone の役割を究明する目的 で, 本症患者の尿中 aldosterone 排泄量をその臨床経過を追つて測定し, 新たな知見を得たので報告する。

他方重症筋無力症においては諸種内分泌異常を合併するてとが多いとされており, 著者の経験した10例に おいても, 糖同化機能異常, 甲状腺機能異常, 胸腺腫および異常残存胸腺など些認める例が多く, てれら内 分泌機能についても言及したい.

\section{測 定 法}

著者は Neher \& Wettstein 法2) に基ずくHernando ら ${ }^{3)}$ の測定法に改良を加えた久田氏変法 ${ }^{4}$ にほぼ準 じて尿中 aldosterone 排泄量の測定を行なつた.

(A) 試 薬

1) Ghloroform : Aldosterone 用特級品に1/5容の 2,4-dinitrophenyl hydrazine 試薬を加え還流冷却器 を用いて約 $75^{\circ} \mathrm{C} に て 3$ 時間加熱し，脱 aldehyde 後室温にて放置冷却し chloroform 首を分離し，之に無 水硫酸ソーダを加えて脱水後再蒸溜を行ないその㠹溜分を使用した。

2) Methanol : 特級品を再蒸溜して使用した.

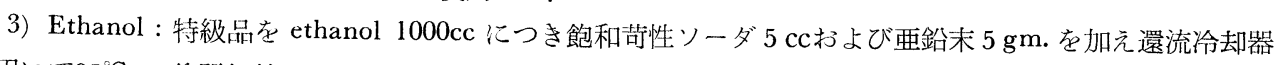
を用いて $95^{\circ} \mathrm{C} 30$ 分間加熱し, 脱 aldehyde 後再蒸溜を行なつて使用した.

4）濃塩酸：特級試薬を使用した.

5) $1 / 10 \mathrm{~N}-\mathrm{NaOH}$ : 特級苛性ソーダ試楽 $4 \mathrm{gm}$. を蒸溜水 $1000 \mathrm{cc}$ 中に溶解し使用した.

6) Formamide : 和光製純薬品を使用した.

7) Acetone : 特級試薬を使用した.

8) Toluene : 特級試薬を使用した.

9) Ethyl acetate : 特級試薬を再蒸溜し使用した.

10）無水硫酸ソーダ：特級品を desiccator 中に保存し使用した.

11) Blue tetrazolium : Nutritional Biochemicals Corporation, Cleveland, Ohio. Lot No. 3839 を用 いた。

12) $10 \%$ Tetramethylammonium hydroxide 水溶液 : 東京化成製品在使用した.

13) Florisil : 60-100mesh, Floridin Co. 製を特級 ethanol に一㡺夜浸漬し，その間 4 -5 回 ethanol を 取り替える。かくして得た florisil を更に ethanol で 2 回洗涤し, glass fiber filter で濾過乾燥させ, 更に 
之を電気炉で $600^{\circ} \mathrm{C} 4$ 時間加熱した。活性化した florisil は放冷後 desiccator 中に保存し，4 日以内に使用 した.

14）Filter paper：東洋濾紙 No. 51を予め数本の脚を有する様に作成し ${ }^{4}$ ，精製 chloroform 中に浸した 後に取り出し乾燥後, Soxlet 装置を用いて ethanol で48時間洗涤後使用した.

15）標品 Aldosterone*1)：エーザイ製薬提供の Vismara Terapeutici, Lot No. 55563126825 在使用し た.

16）標品 Cortisone および Hydrocortisone：帝国藏器および塩野義製薬提供の cortisone free および hydrocortisone free を使用した.

17) Sudan III : Hexane 中に溶解して用いた。

18）水：イオン交換樹脂純水精製装置より得た $\mathrm{Cu}^{++}$を含まない純水を使用した.

(B) 測 定 法

Fig. 1. Our method of determination of urinary aldosterone by the modified method of Neher \& Wettstein

Urine sample

cooled and collected over a 24-hour urine with $15 \mathrm{cc}$ glacial acetic acid, protected from light

Hydrolysis

allowed to stand at room temperature for 24 hours after acidifying to $\mathrm{pH} 1.5$ with conc. hydrochloric acid

Extraction (twice) added with 0.5 vol. chloroform and shaked with a continuous mechanical shaker for 6 hours Emulsion is separated by centrifuging

-Washing

a) with $0.05 \mathrm{vol} .0 .1 \mathrm{~N}$ sodium hydroxide solution (twice)

b) with 0.05 vol. dist. water until the washings are neutral to litmus paper (twice or more)

Each washing is back extracted with 0.5 vol. chloroform and added to the extract

-Dehydration with sodium sulphate and filtered

-Evaporating in vacuo in water bath below $50^{\circ} \mathrm{C}$

Florisil column chromatography the portion of $45 \mathrm{cc} 25 \%$ methanol-chloroform is evaporated

First paper chromatography (Zaffaroni F-C System) the location of aldosterone is checked by using UV lamp with corning filter No. 9896 and the strip of $6 \mathrm{~cm}$ width $(5 \mathrm{~cm}$ above $\& 1 \mathrm{~cm}$ below) corresponding with the bottom line of standard cortisone is cut out. The aldosterone spot is eluted in methanol for 24 hours after drying below $50^{\circ} \mathrm{C}$ overnight and evaporated

Second paper chromatography (Bush C System)

hydrocortisone is used as standard and other procedure

is same as described in F-C system

Blue Tetrazolium reaction

।

Spectrophotometry $(510 \mathrm{~m} \mu)$

I

Evaluation from a standard curve with d-aldosterone 
Fig. 1 亿著者の測定法の概略を示す.

\section{1）加水分解之抽出}

水水を用いて $5{ }^{\circ} \mathrm{C}$ 以下の暗室にて貯えた 24 時間尿を， $\mathrm{pH}$ meter を使用し湦塩酸を加えて $\mathrm{pH} 1.5$ とし， 室温にて 24 時間放置し加水分解を行なつた。，次いで $1 / 2$ 容の精製 chloroform を加え機械振湯機を用いて 6 時間振盪, ての操作を 2 度くり返して抽出を行なつた。抽出液は $1 / 20$ 容の $1 / 10 \mathrm{~N}-\mathrm{NaOH}$ 液で 2 回洗涤し, 次いで $1 / 20$ 容の蒸溜水で抽出液がリトマス中性となるまで 2 回以上洗滌を行ない，かようにして得た洗涤液 は1/2量の chloroform にて逆抽出を行ない，之を元の抽出液に加え，更に之に少量の無水硫酸ソーダを加 えて脱水を行なつた後に $50^{\circ} \mathrm{C}$ 以下の温度にて減圧蒸溜乾固を行なつた。

\section{2) Column chromatography}

内径 $1 \mathrm{~cm}$ 高さ $7 \mathrm{~cm} の$ column に ethanol を用いて湿式にて florisil をつめ, 之に前述の方法で乾固し た粗抽出物を chloroform 10cc にて溶出した液を注入吸着せしめ, 更に chloroform 5cc にて 2 回容器を 洗涤し column に注入した.

次いで 1\% methanol-chloroform 液 25cc，更に 25\% methanol-chloroform 液 45cc を1 分間約60滴 の速度で column を通し， aldosterone が溶出される後者の分画 $45 \mathrm{cc}$ を採取し，之を $50^{\circ} \mathrm{C}$ 以下で減圧乾固 した.

3) Paper chromatography

a) First paper chromatography (Zaffaroni F-C System)

前述の方法で精製した滤紙を 30\% formamide acetone 溶液に浸した後に之を暫時空気中で乾燥させ余 分の液は濾紙を用いて吸着除去し，ての濾紙の起始点上に column chromatography を行なつて得た乾固 物を少量の chloroform に溶解した液を spot し，他脚にそれぞれ cortisone, hydrocortisone の methanol 溶液を spot し，更に Sudan III を pilot として spot した。 上述の方法ですばやく spot した濾紙を室温 にて formamide 飽和 chloroform 液を溶媒としたタンク中で 4-6 時間展開し，Sudan III で示された solvent front が脚の先端 $5 \mathrm{~cm}$ 以内に達した時に濾紙をタンク中より取り出し， $50^{\circ} \mathrm{C}$ 以下の乾燥器中で一㡺 夜乾燥させた．次いでマツダ殺菌灯 (GT1511A) を光源とし Corning filter (No. 9863) を通して cortisone spot に相当する部分を, 上 $5 \mathrm{~cm} 1 \mathrm{~cm} の 6 \mathrm{~cm}$ 币に切り取り, $10 \mathrm{cc} の$ methanol で一夜溶出後更に約 $10 \mathrm{cc}$ の methanol で容器を洗條した。乙の溶出液を $50^{\circ} \mathrm{C}$ 以下にて減圧乾固し，次の操作を行なつた，

b) Second paper chromatography (Buch C System)

この乾固物を少量の chloroform 飞溶解し，前述の方法で精製した濾紙の起始点上に spot し，他脚にそ れぞれ cortisone, hydrocortisone を spot して, 之を $37^{\circ} \mathrm{C}$ 亿安定させた Bush 溶媒 (Toluene : Ethyl acetate : Methanol : Water ; 9:1:1:5) 液の固定相の蒸気中で 3ー4 時間吊した後に，之に移動相を注入 し $3-5$ 時間展開した。 この Bush C 系では aldosterone は hydrocortisone とほぼ同じ Rf 值を有する ので，先の F-G系と同様にして hydrocortisone 亿一致する spot を $6 \mathrm{~cm}$ 巾に切り取り，他方何も spot してない脚より同じく $6 \mathrm{~cm}$ 巾に切り取り paper blank とし，同様に減圧乾固した

\section{4) 比色 定 量}

上述の操作を経て精製した試料および paper blank より得た乾固物をそれぞれ 3 ccの精製 ethanol に溶 解し, 之に 10\% tetramethylammonium hydroxide 水溶液を精製 ethanol で溶解した溶液 $0.5 \mathrm{cc}$ および $0.1 \mathrm{gm}$ blue tetrazolium を精製 ethanol $20 \mathrm{cc}$ に溶解した過飽和溶液の上清（500 $\mathrm{mg} \%) \quad 0.5 \mathrm{cc}$ を加え，振 晹しながら充分混和し，室温暗所にて25分間放置し発色を確認してから水醋酸 $2 \mathrm{cc}$ を加えて発色を停止させ た. 次いで之を Bechman 型 spectrophotometer を用い波長 $510 \mathrm{~m} \mu$ の吸光度にて比色して得た值から paper blank の值を差し引き, hydrocortisone $1 \mu \mathrm{g}$ の平均值 (0.0090) より換算算出した。 尚 d-aldosterone を入手後は，乙れを用いて作成した標準曲線を使用した（Fig. 2).

5 ) 測定法の検討, 正常值並びに回収率

著者の行なつた測定法と Neher \& Wettstein 法との相違点は，a）尿採取に際し 3 倍に稀䣋した氷醋酸15cc 
Fig. 2. Standard curve (at $510 \mathrm{~m} \mu$.)

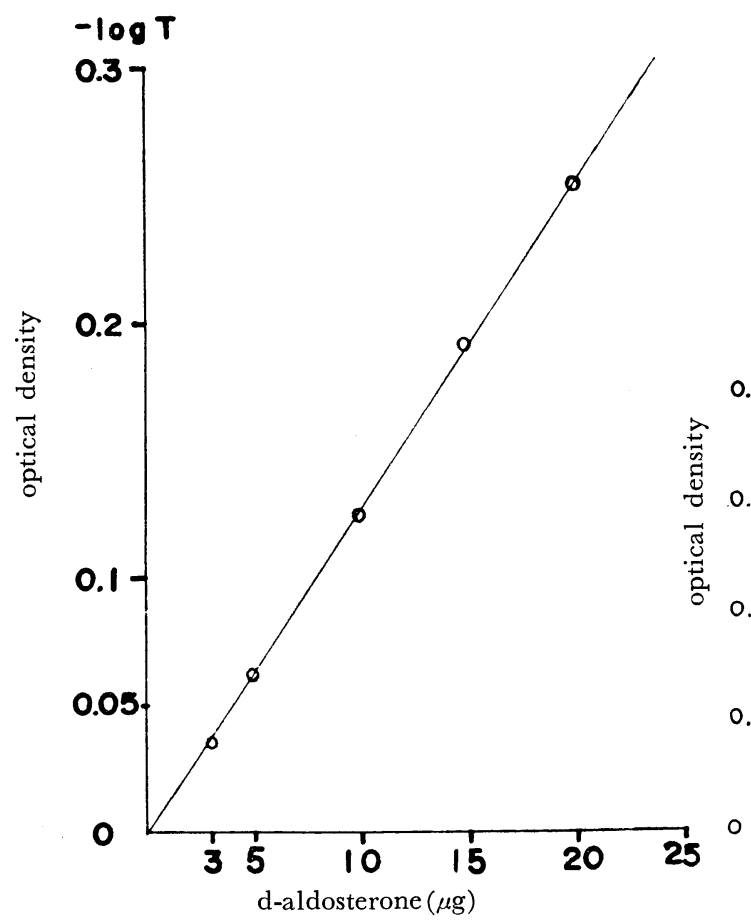

Fig. 3. Absorption spectra of free aldosterone, urine extract and reagent blank with blue tetrazolium reaction

\section{$\multimap 20 \mu g$ aldosterone \\ $x \longrightarrow$ urine extract \\ $\longrightarrow$ reagent blank}

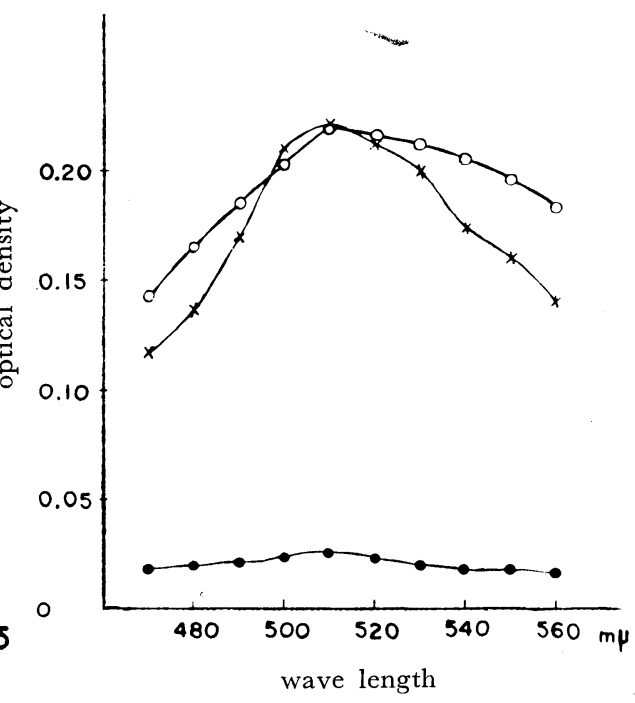

を加え氷水を用いて $5{ }^{\circ} \mathrm{C}$ 以下の泠暗所で蓄尿したとと，b) 抽出は機械振盪機を用い $1 / 2$ 容の精製 chloroform を加え 6 時間振盪を 2 度行なつたとと, c) Silica gel の代りに florisil を用いて column chromatography を行なつたとと，d) Aldosterone spot の決定にマツダ殺菌灯を光源とし Corning filter を使用したてと， e) Aldosterone 值は blue tetrazolium 反応により比色し別に作成した d-aldosterone free の標準曲線よ り算出したてと（当初は aldosterone の入手不能のため, hydrocortisone $1 \mu \mathrm{g}$ の平均值より換算算出した こと）等である。尚久田氏変法と異なる主な点は, 抽出に Cohen type の連統抽出器を使用せず機械振盪 機を用いた点である.

著者の方法で得た d-aldosterone free, 尿抽出物および paper blank の peak は Fig. 3 に示す如く $510 \mathrm{~m} \mu$ であり, paper blank の平均值は $0.025 \pm 0.002$ であつた.

尚著者の方法で測定された物質は $2 つ の$ paper chromatography の Rf 值より aldosterone に相違ない と考えられたが，食塩制限中の高血圧症患者尿より得られた試料について次の検討を行なつた。紫外線吸 収 ${ }^{5}$ ， Blue tetrazolium 反応 ${ }^{6)}, \mathrm{H}_{2} \mathrm{SO}_{4}$ chromogenの吸収スペクトルの測定 ${ }^{7)}$ を行ない, Simpson ら ${ }^{8)}$ と同 様の結果を得た。尚 $\mathrm{H}_{2} \mathrm{SO}_{4}$ chromogen の吸収スペクトルの測定では $288 \mathrm{~m} \mu$ peak を有し, 著者の試 料が aldosterone に相違ないものと考えられた。

第 1 次および第 2 次の paper chromatography のみの回収率はそれぞれ 84.0 および $82.5 \%$, 煮沸尿 $900 \mathrm{ml}$ にd-aldosterone free $30 \mu \mathrm{g}$ を加えて行なつた全操作を通じての回収率は 55.0一 59.3\% (平均57.7 \%) であつた.

健康成人 8 例（男 4 例，女 4 例）より得られた尿中 aldosterone 排泄值は 2.2-11.2 $\mu \mathrm{g} / \mathrm{day}$ で, その平均 值は $5.5 \pm 2.2 \mu \mathrm{g} /$ day であつた.

6 ）電解質および他の Hormone 測定法 
血清および尿中電解質 (Na およびK) の測定は日立 IIPF Flame Photometer を使用した.

尿中 17-ketosteroids (以下 17-KS) は Drekter らの方法9)，17-hydroxycorticosteroids (以下 17-OHCS)

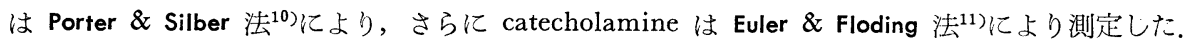

\section{実験対象および実験方法}

対象は 1963 年以来当科に入院した電撃型 2 例, 全身型 4 例および眼瞼型 4 例からなる重症筋無力型患者 10 例について行ない，全例共普通食を与え，特に電解質の負荷および制限は行なつていない，

尿中 aldosterone およびその他の尿中 hormone の測定は extremity weakness を有する時期およびてれ を欠く時期に測定を行なつたが，両時期に亘つて測定可能であつたのは電撃型の 1 例および全身型の 3 例の 計 4 例であつた。電撃型の他の1例は常に extremity weakness 在有し， myasthenic crisis で死亡したた め, 又全身型の他の1例は抗 $\mathrm{ChE}$ 㓮投与に抗し寛解を見なかつたため，共に extremity weakness を欠く 時期を有せず，眼臉型の 4 例之共に，両時期に亘つて観察することは出来なかつた。

Extremity weakness の程度は臨床症状および臨床所見特に両腕を水平に保ちうる時間で判定した。尚全 例共 Tensilon*2) test 陽性であつた。

結果

眼瞼型の 3 例（Y.S., F.O. および F.O.）を除く他の 8 症例の臨床所見，検查所見および治療状沉につい ては Fig. 4 より Fig. 10 までに示した.

全症例の尿中 aldosterone, 17-KS, 17-OHCS, catecholamine, 血清 $\mathrm{Na}$ およびK 值更に尿中 $\mathrm{Na} / \mathrm{K}$ 比を extremity weakness の有無による時期に分け Table 1 亿示した. Fig. 11 亿示す如く, extremity weakness を有する時期に尿中 aldosterone 排泄量の明らかな增加を認め, かつ extremity weakness の消失せる時 期に aldosterone 值の正常化を認めた。本症患者に抗 $\mathrm{ChE}$ 剂*3)を投与した際に尿中 aldosterone 值に影 響をおよぼすか否かを実験的に確かめることは困難であるが，眼瞼型H.Y.例（Fig. 10）について行なつた

Fig. 4.
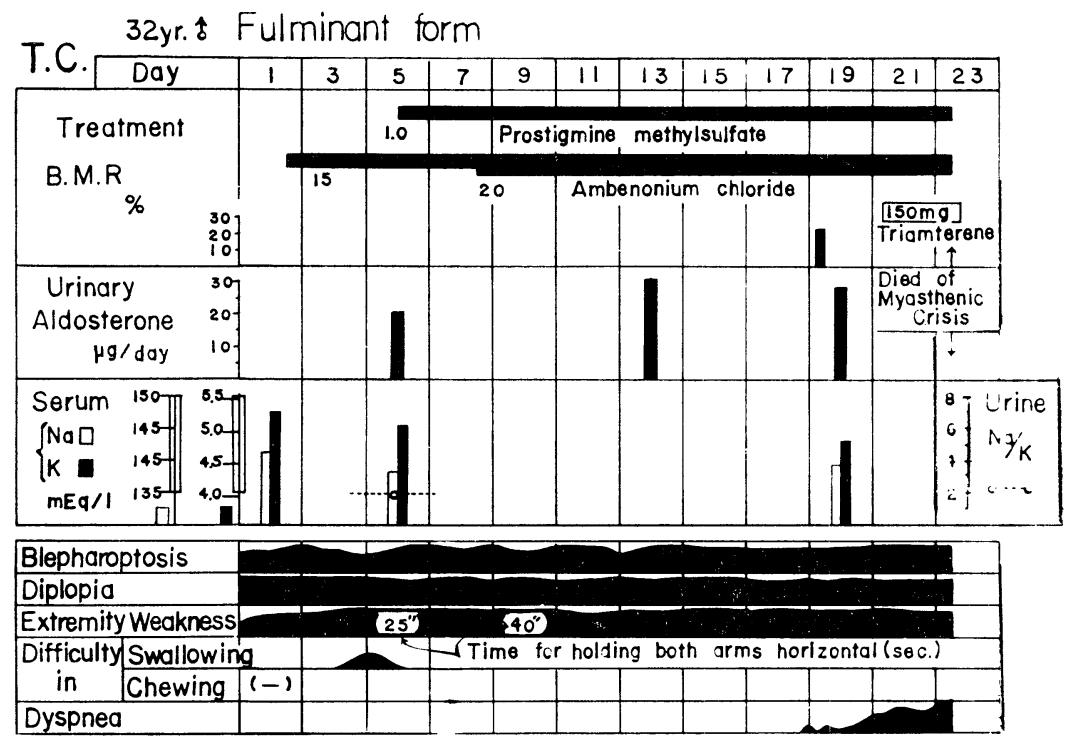

Onset: January 1963 Admission: June 41963 
Fig. 5.
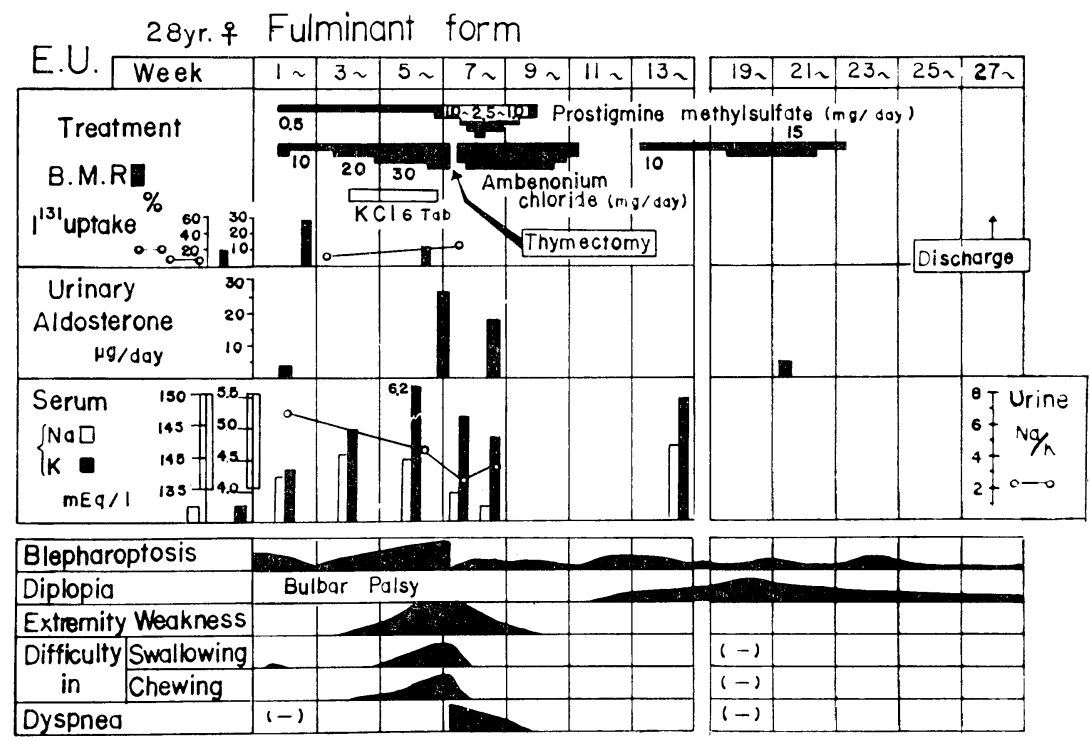

Onset: May 1963 Admission: July. 91963

Fig. 6.
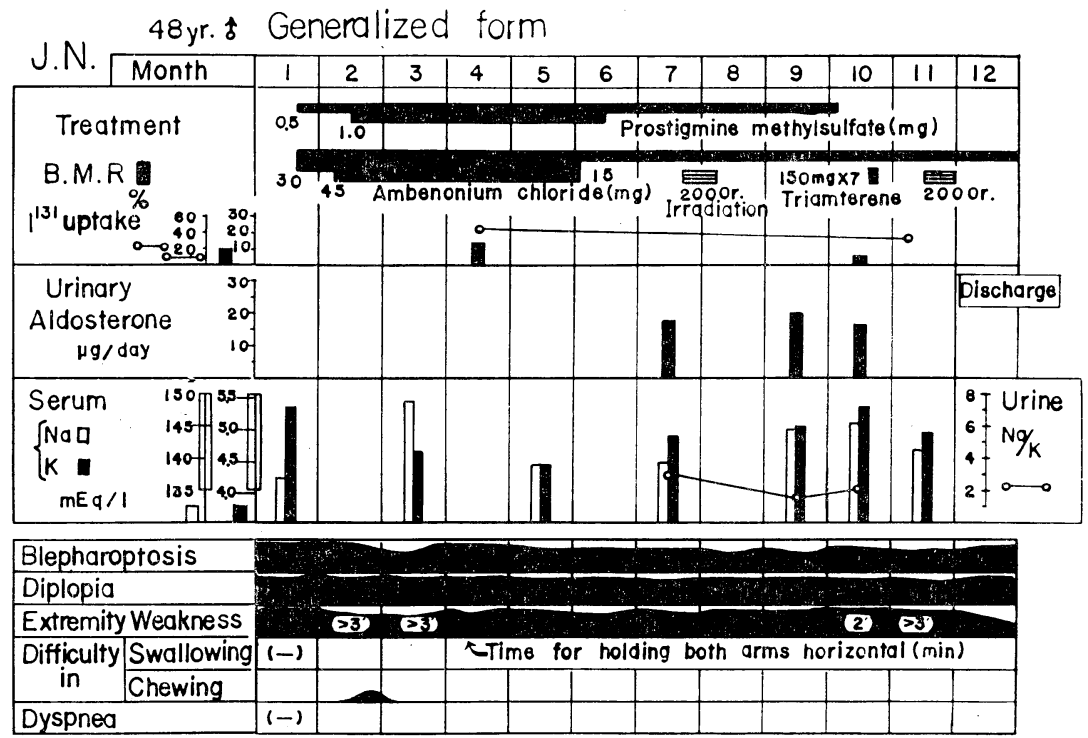
Fig. 7.

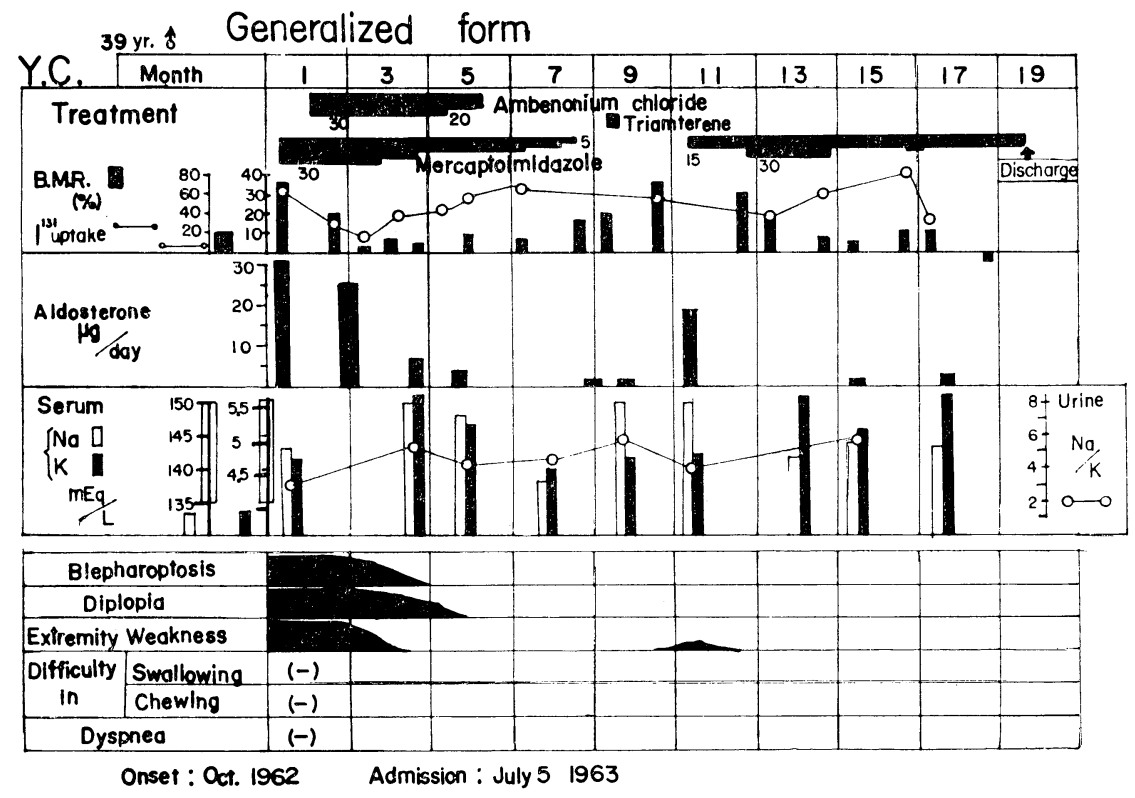

Fig. 8.

3lyr. \& Generalized form, with Primary Myxedema
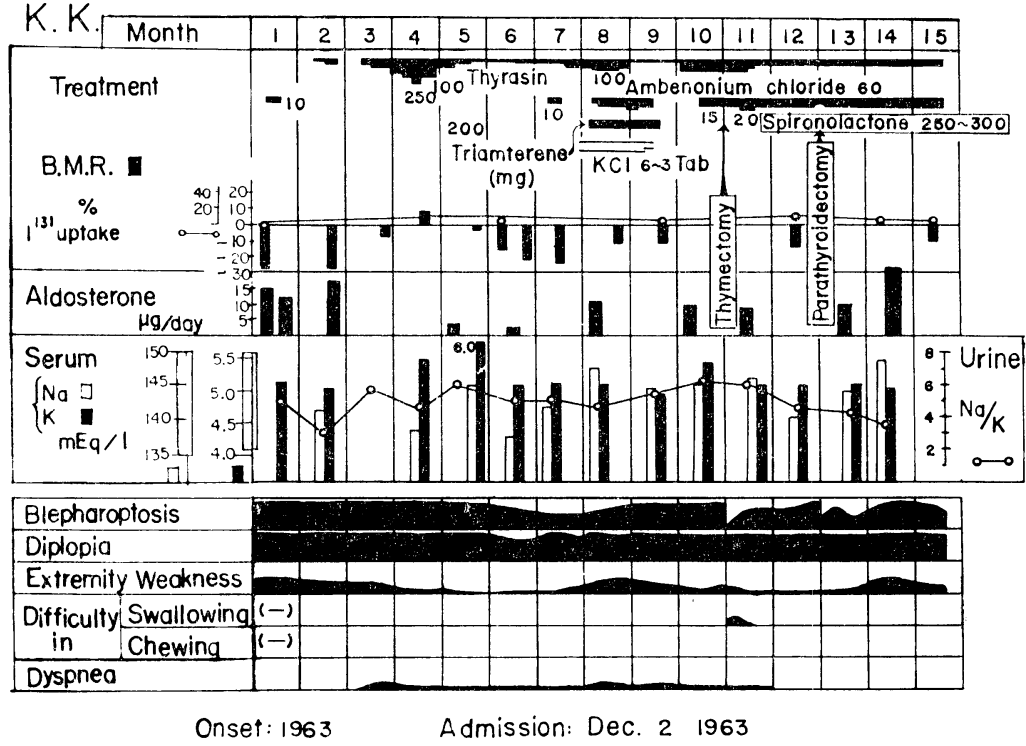
Fig. 9.
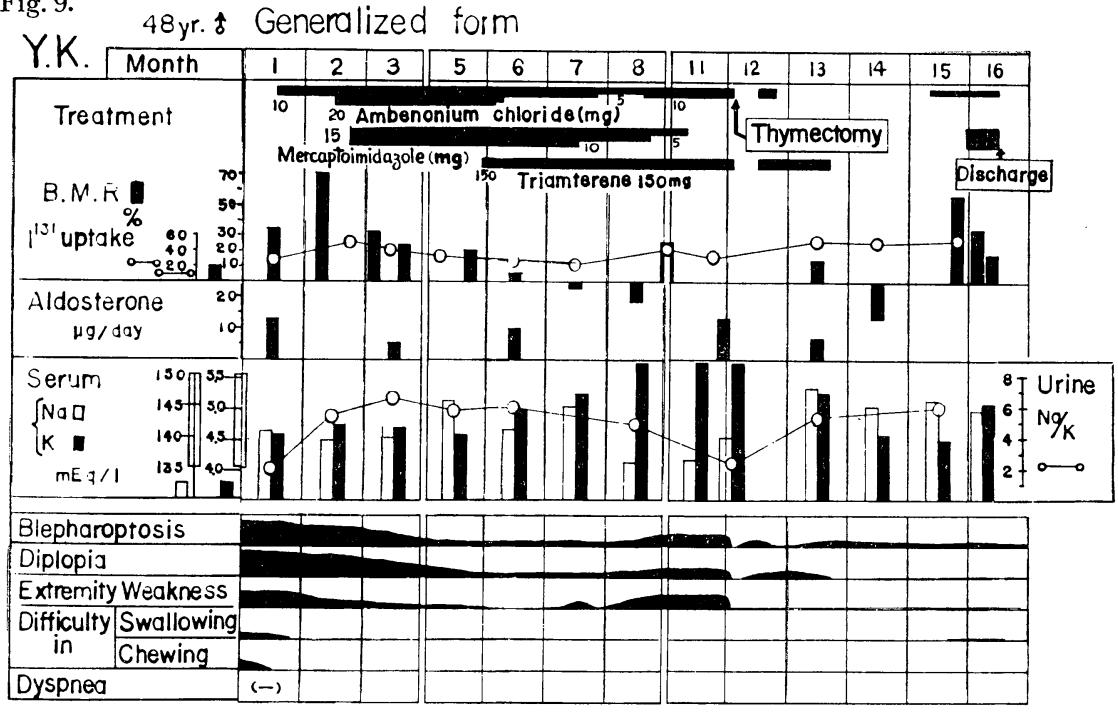

Onset : July. 1964 Admission: Sept. 71964

Table 1. Urinary excretion of aldosterone, 17-ketosteroids, 17-hydroxycorticosteroids

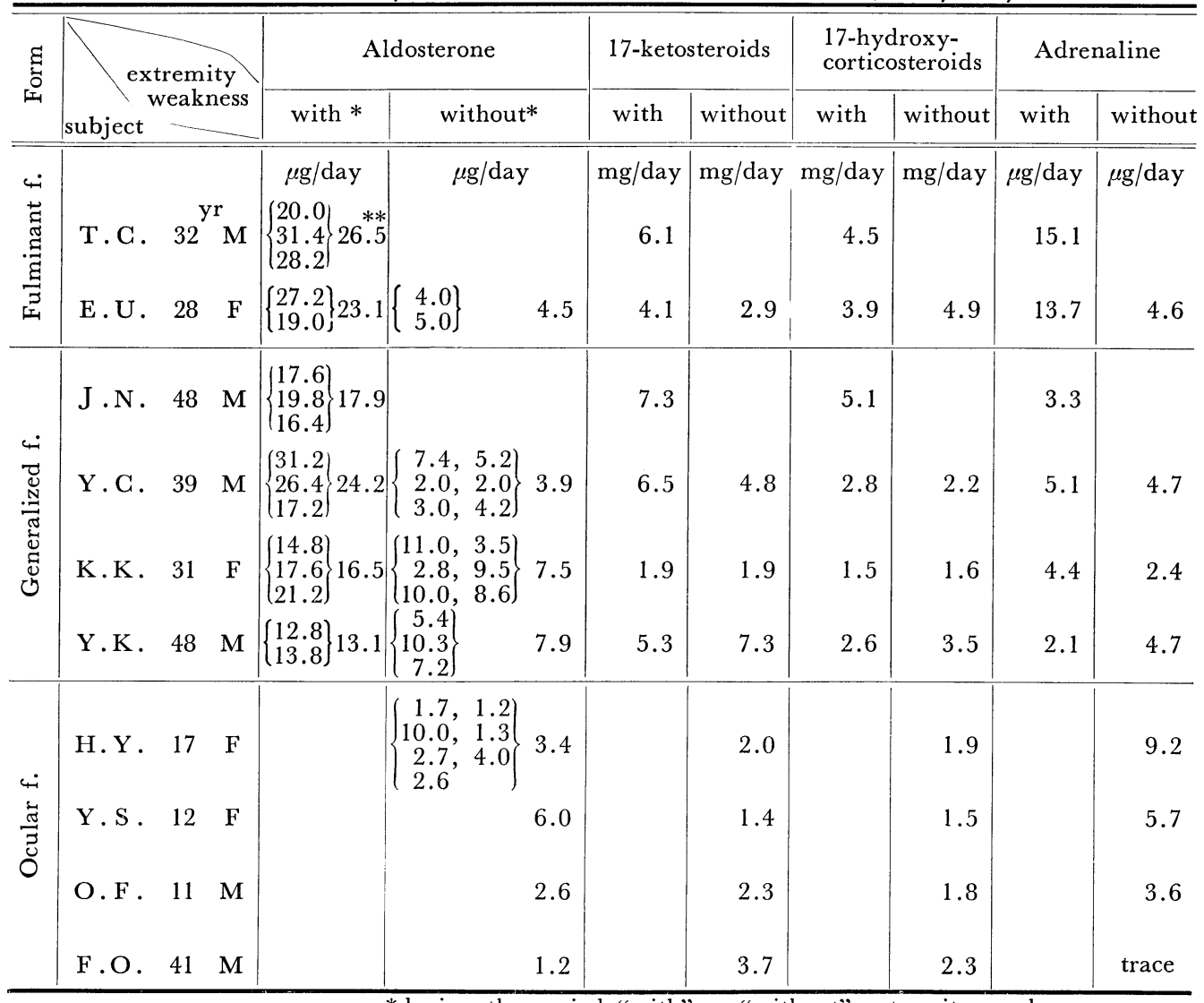

*during the period "with" or "without" extremity weakness 
Fig. 10. $17 y+$ O Ocular form
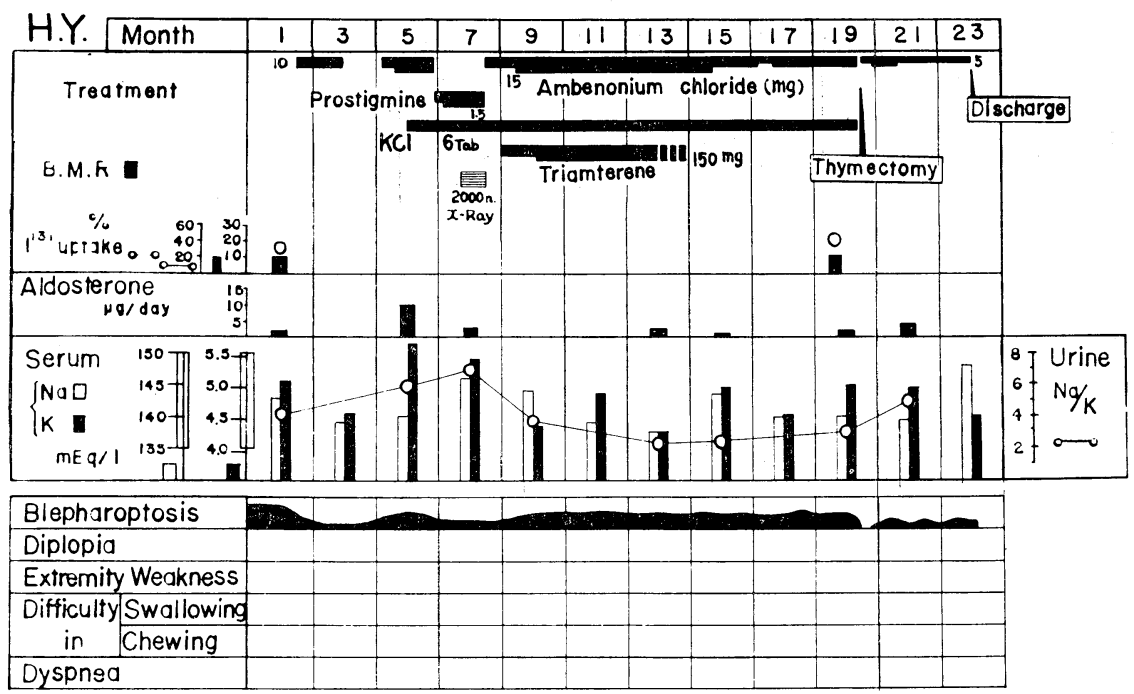

Onset: Nov. 1960

Admission: Apr.29 1964

catecholamine, and serum \& urinary electrolytes in patients with myasthenia gravis

\begin{tabular}{|c|c|c|c|c|c|c|c|c|}
\hline \multicolumn{2}{|c|}{ Noradrenaline } & \multicolumn{2}{|c|}{ Serum Sodium } & \multicolumn{2}{|c|}{ Serum Potassium } & \multicolumn{2}{|c|}{ Urinary $\mathrm{Na} / \mathrm{K}$} & \multirow{2}{*}{ Nots } \\
\hline with & without & with & without & with & without & with & without & \\
\hline$\mu \mathrm{g} / \mathrm{day}$ & $\mu \mathrm{g} / \mathrm{day}$ & $\mathrm{mEq} / \mathrm{l}$ & $\mathrm{mEq} / \mathrm{l}$ & $\mathrm{mEq} / \mathrm{l}$ & $\mathrm{mEq} / 1$ & & & \\
\hline 37.2 & & 138.5 & & 5.0 & & 3.4 & & $\begin{array}{l}\text { hypertension } \\
\text { died of myasthenic } \\
\text { crisis }\end{array}$ \\
\hline 10.7 & 22.0 & 137.0 & 138.7 & 5.1 & 5.1 & 3.0 & 6.6 & $\begin{array}{l}\text { hypertension } \\
\text { thymectomy }\end{array}$ \\
\hline 12.9 & & 141.5 & & 4.9 & & 5.1 & & $\begin{array}{l}\text { anti-cholinesterase } \\
\text { therdpy is ineffective }\end{array}$ \\
\hline 42.2 & 24.5 & 148.5 & 145.2 & 4.7 & 5.6 & 3.0 & 4.2 & hyperthyroidism \\
\hline 21.0 & 31.0 & 139.6 & 143.9 & 5.0 & 5.5 & 4.0 & 4.7 & $\begin{array}{l}\text { hypothyroidism } \\
\text { thymectomy }\end{array}$ \\
\hline 52.5 & 19.1 & 140.9 & 142.7 & 4.6 & 4.9 & 2.8 & 5.1 & $\begin{array}{l}\text { hyperthyroidism } \\
\text { thymectomy }\end{array}$ \\
\hline & 36.4 & & 141.5 & & 5.7 & & 4.7 & $\begin{array}{l}\text { no extremity weakness } \\
\text { thymectomy }\end{array}$ \\
\hline & 21.1 & & 145.0 & & 5.0 & & 4.7 & no extremity weakness \\
\hline & 23.6 & & 143.0 & & 5.4 & & 4.3 & $\begin{array}{l}\text { no extremity weakness } \\
\text { thymectomy }\end{array}$ \\
\hline & 31.4 & & 141.2 & & 4.7 & & 4.8 & no extremity meakness \\
\hline
\end{tabular}

**the average value of the determined value shown in parentheses

第43巻 第 8 号 
Fig. 11. Concentrations of urinary aldosterone, serum sodium \& potassium, and urinary sodium to potassium ratio during the periods "with" and/or "without" extremity weakness

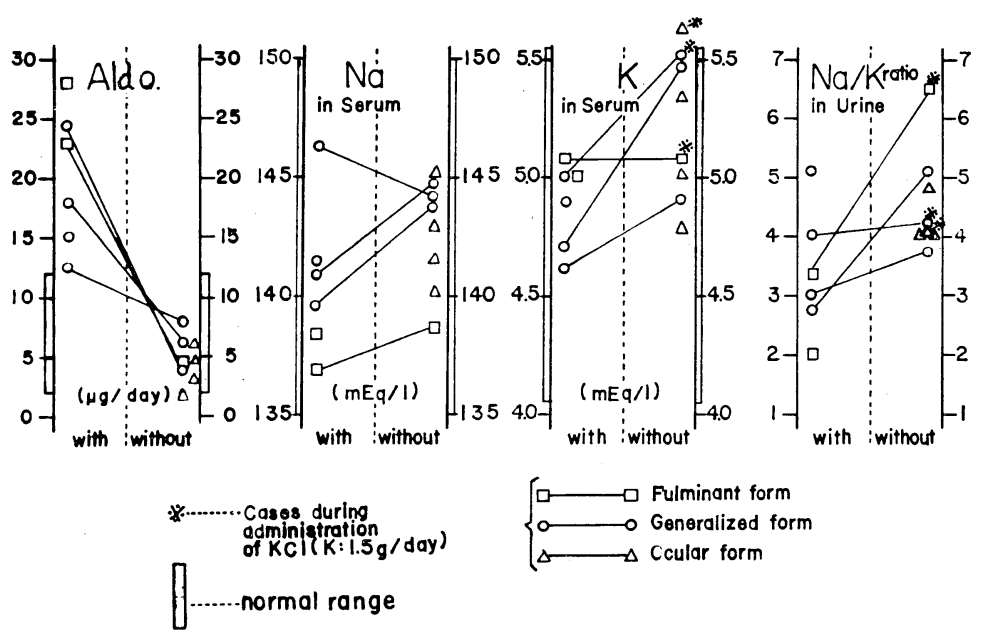

Fig. 12. Concentrations of 17-ketosteroids, 17-hydroxycorticosteroids and catecholamine during the periods "with" and/or "without" extremity weakness
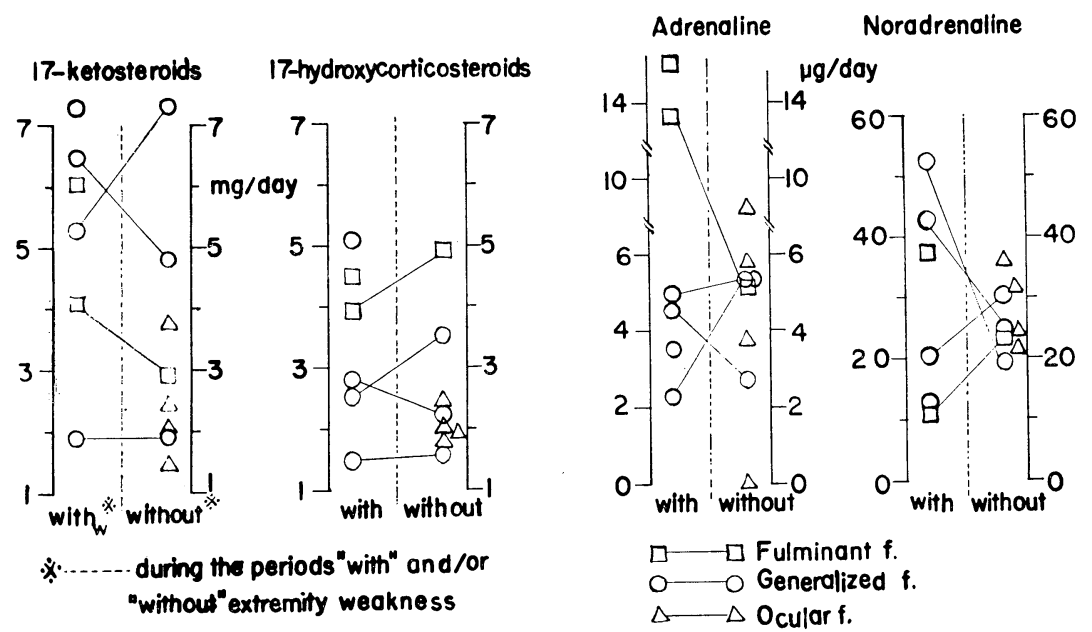

結果より抗 $\mathrm{ChE}$ 剂投与が aldosterone 排泄量に特別の影響を与光ないものと想像された。 T G. および J.N.の 2 例（Fig. 4，6）でもほぼ同様のととが云いうる。この両例では抗 ChE 骫を投与しても extremity weakness の改善をみていない点が特に重要だと考光られる. 全身型のY.C.例（Fig. 7) で明らかな如く, 尿中 aldosterone 排泄量の減少は, 抗 $\mathrm{ChE}$ 剂そのものの影響ではなく, むしろ同剤の奏効による extremity weakness の消失と共に起つたものと考觉られる.

次に Fig. 12 亿示す如く, 17-KS および 17-OHCS 值には aldosterone 值にみられる様な有意の変動は 認められなかつた。 
Table 2. Another findings of clinical and laboratory examinations

\begin{tabular}{|c|c|c|c|c|c|c|c|c|c|c|c|}
\hline & \multirow{2}{*}{$\begin{array}{l}\text { Form } \\
\text { Cases } \\
\text { Age. Sex }\end{array}$} & \multicolumn{2}{|c|}{ Fulminant $\mathrm{f}$. } & \multicolumn{4}{|c|}{ Generalized f. } & \multicolumn{4}{|c|}{ Ocular f. } \\
\hline & & $\begin{array}{l}\text { T. G. } \\
32 \hat{o}\end{array}$ & $\begin{array}{l}\text { E.U. } \\
28 \text { 우 }\end{array}$ & $\left|\begin{array}{c}\mathrm{J} . \mathrm{N} \\
48 \hat{\delta}\end{array}\right|$ & $\begin{array}{c}\text { Y. G. } \\
39 \AA\end{array}$ & $\left|\begin{array}{c}\mathrm{K} . \mathrm{K} . \\
31 \text { 우 }\end{array}\right|$ & $\begin{array}{l}\mathrm{Y} . \mathrm{K} . \\
48 \hat{\delta}\end{array}$ & $\begin{array}{l}\text { H. Y. } \\
17 \text { 우 }\end{array}$ & $\begin{array}{c}\mathrm{S} . \mathrm{Y} \\
12 \text { 우 }\end{array}$ & $\begin{array}{l}\mathrm{O} . \mathrm{F} . \\
11 \hat{\delta}\end{array}$ & $\begin{array}{l}\text { F.O. } \\
41 \hat{\delta}\end{array}$ \\
\hline \multicolumn{2}{|c|}{ Tention Test } & + & + & + & + & + & + & + & + & + & + \\
\hline $\begin{array}{l}\text { E.M.G. } \\
\text { findings }\end{array}$ & $\begin{array}{l}\text { waning } \\
\text { low voltage }\end{array}$ & + & + & + & + & $\begin{array}{l}+ \\
+\end{array}$ & $\begin{array}{l}+ \\
+\end{array}$ & + & + & & \\
\hline \multirow{2}{*}{ Muscle biopsy } & atrophy & $H$ & + & + & + & + & + & + & & & \\
\hline & degeneration & + & & + & + & + & + & & & & \\
\hline \multicolumn{2}{|c|}{$\mathrm{Na} / \mathrm{K}$ ratio in muscle tissue } & & & & $1 / 2.2$ & $1 / 1.5$ & & $1 / 1.2$ & & & \\
\hline \multicolumn{2}{|c|}{ Urine sugar } & + & + & - & - & - & - & - & - & - & - \\
\hline \multirow{2}{*}{ G.T.T. } & fasting time & 119 & 107 & 50 & 87 & 77 & 102 & 75 & 88 & & \\
\hline & $\begin{array}{c}\text { after } 60 \text { min. } \\
\text { (depletion of } 50 \mathrm{~g} \text { ) }\end{array}$ & 203 & 223 & 90 & 124 & 78 & 178 & 78 & 126 & & \\
\hline \multicolumn{2}{|c|}{ Struma } & - & - & - & + & - & + & - & - & - & - \\
\hline \multicolumn{2}{|c|}{ Thymoma in chest X-ray } & + & - & - & - & - & \pm & - & - & - & \pm \\
\hline \multicolumn{2}{|c|}{$\begin{array}{l}\text { Thymus weight in cases, } \\
\text { accepted "Thymectomy" }\end{array}$} & & $35 \mathrm{~g}$ & & & $50 \mathrm{~g}$ & $14 \mathrm{~g}$ & $29 \mathrm{~g}$ & & & \\
\hline
\end{tabular}

Fig. 13. Influences on concentrations of urinary aldosterone, serum sodium \& potassium, and urinary sodium to potassium ratio after thymectomy
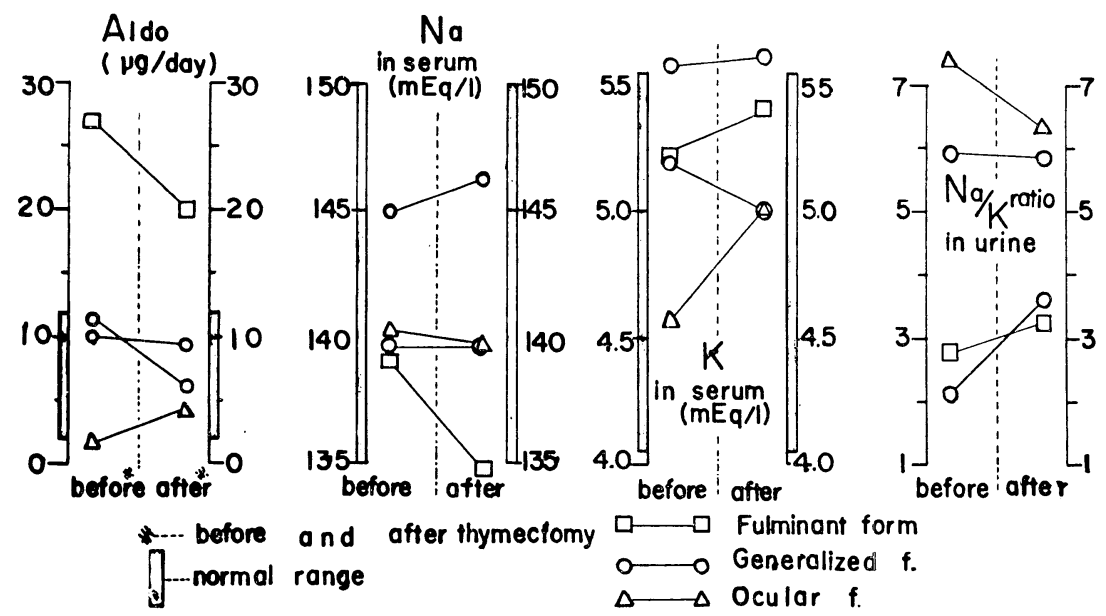
尿中 adrenaline 值は高血圧を有する電撃型の 2 例 (T.G.およびE.U.例) で軽度上昇を認め, 又 noradrenaline は甲状腺機能元進を示した例（Y.C.）で軽度増加を示したが， extremity weakness の有無によ る有意の変動は認められなかつた。

Aldosterone 排泄量と甲状腺機能との関係についても一定の傾向は認められなかつた.

次に他の内分泌機能との関係をみると (Table 2), 糖同化能の異常を認めた例が 10 例中 3 例もあり, 第 1 ちよび第 2 例で尿糖陽性, 糖負荷試験にて60分值の增加を認めた. 第 3 例は逆に低血糖の傾向にあつた。 甲 状腺機能亢進 (甲状腺腫) を認めたものが 2 例あり, 又胸部レ線で明らかな胸腺腫を認めたもの1例, 又胸 腺摘出術を施行した 4 例共年令に比し脂肪化の少い異常残存胸腺を認め得た.

次にK.K.例 (Fig. 8) では Spironolactone*4) 投与時に尿中 aldosterone 増加を示しているが，同剂投 与前および服用 1 か月半後の aldosterone 值に差がないととより，同剤の直接の影響ではないと思われる。 これは同時期に臨床的に extremity weaknes の出現を認めておりその影響と考えるのが孚当と思われる. 次に胸腺摘出術の影響をみると Fig. 13 に示す如く一定の関係は認められなかつた。 てれは又 E.U. および K.K.例の経過表 (Fig. 5 および Fig. 8) より明らかである.

血清 $\mathrm{Na}$ およびK值については，Fig. 11 そ示す如く，Na 值は 3 例で extremity weakness を欠く時期 で逆に増加しており, aldosterone 值の低下, 血清 $\mathrm{K}$ 值の増加および尿中 $\mathrm{Na} / \mathrm{K}$ 比の增加等と一致しなか つたが，乙の変動は全て正常範囲内のものであり，特に有意の差はないと考えられた，血清 $\mathrm{K}$ 值は尿中 aldosterone 值の減少とほぼ一致して増加していた。 尿中 $\mathrm{Na} / \mathrm{K}$ 比も同様に aldosterone の変動とほぼ一 致して増加していた.

\section{考案}

1961年 Gottlieb および Laurent ${ }^{12)} に よ り ，$ 重症筋無力症に抗 aldosterone 剂*45) が有効であるという報 告がはじめてなされ，以来本症の筋組織における電解質代謝が再び注目される様になつた。 しかし本症にお ける aldosterone 代謝に関する報告は殆ど見当らない.

最近Frenkel ら $\left.{ }^{13}\right)$ にり, 月経前期に筋力低下を示す重症筋無力症の婦人患者 3 例で排卵後の progesterone 排泄增加にひき続いて尿中 aldosterone 排泄量の増加を認め, 乙れら患者に progesterone および DOGA

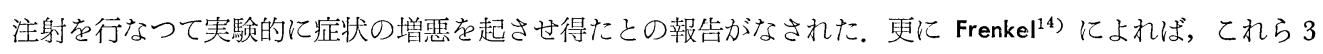
例の患者に排卵抑制の目的で Norethynodrel (Enovid)*6) を投与して progesterone 産生を抑制し月経前期 の症状増覀も阻止出来たてとより，本症の増悪因子として aldosterone の排泄増加が考えられるととを実証 した。 しかるに Frenkel の報告では, 月経前期に症状增悪を示さない他の婦人患者および男子患者について の尿中 aldosterone 排泄量の記載はなく, 又本邦では冲中ら ${ }^{15}$ の 1 例で aldosterone 排泄量は正常であつ たという報告があるのみである。しかるに本症患者の症状增悪は，婦人患者においてさえ，その大半は月経 周期とは無関係に起るのであり，かつ他の男子例も含めて抗 aldosterone 剤が有效だとする報告は多い12)16) 17)18).

他方周期性四肢麻痺発作においては，麻痺発作の際に血清 $\mathrm{K} か ゙$ 著明に低下することが明らかにされており ${ }^{19}{ }^{20)}$, Conn ${ }^{21)}$ は麻瘏の直前に aldosterone 分泌が方進し細胞外液のNaが増加してKが細胞内に移行するた めとし, intermittent hyperaldosteronuria という説を提晿した． 以来本症の筋肉内外の電解質の变動につ いて数多くの観察がなされているが，麻瘦の際にかならずしも aldosterone 分跳增加を認めない報告があり $\left.{ }^{22}{ }^{23}{ }^{24}\right)$ ，現在では麻痺発作と aldosterone 分泌增加との関係はむしろ否定的の様である.

一方重症筋無力症の際の血清 $\mathrm{K}$ 值は正常ないしは正常下界を示すとされているが25)，本症における細胞内 電解質の変動については, 報告例が少くまだ一定の見解は得られていない様である.

Hypokalemic paralysis は exogenous steroidsによつても起りうるし, 又 aldosterone の分泌が異常に 六進している状態 (Primary aldosteronism) では自然に起りうる.

重症筋無力症は現在の概念では特殊な type に属する neuromuscular conduction の障害によるとされて 
おり，上述の如き hypokalemia や adrenal hyperfunction の徴候も見出されていないのか現状である.

Neuromuscular transmission 機構が正常に働いて筋収縮が起つた際には, 急速な脱分極 (depolarization) が起り，細胞内への Naの移動が起り細胞内Kは減少するとされ，次いで再分極（repolarization）の際には ての逆の移動が起り, Na が細胞外一出てKは細胞内一入る ${ }^{26)}$ とれている.

Grobら ${ }^{27}$ 亿よれば麻瘦発作の発現機序として, 血清Kの低下, 細胞内Kの増加によつて細胞内外カリウム 比 $(\mathrm{Ki} / \mathrm{Ko})$ が上昇し, 静止膜電位が上昇するととより, hyperpolarization block と考えられた. 最近 Creutzfeldt ${ }^{28}$ や里吉ら ${ }^{29}$ は周期性四肢麻瘦で麻痺中の筋細胞静止膜電位が低下していることより, depolarization block と考えられる様になつた。里吉は麻痺時に細胞内の水分が著明に增加するため細胞内K濃度は むしろ低下していると述べているが3031)，他方麻痺発作中軽度の水分增加は認めたが麻痺の有無にかかわら ず細胞内K濃度に殆ど変化はないとし，里吉らの報告を不定した鎮目ら ${ }^{32}$ の報告もある。他方 Dahlbäck ら ${ }^{33}$ および里吉ら ${ }^{29}$ によれば，重症筋無力症の摘出筋の膜電位は正常であり，従つて Grob ら ${ }^{27}$ の四肢麻痺に関 する考光方 (hyperpolarization block) も否定出来ないとしている.

重症筋無力症にみられる extremity weakness を hyperpolarization block と考光た場合には, aldosterone により細胞外Kの細胞内への移動か泖制されることも当然考えられ，従つて Hechter ら ${ }^{34)}$ や Frenkel ら ${ }^{13}$ の DOCA 投与による観察ともよく一致すると思われる。

次に extremity weakness を欠き，尿中 aldosterone 排泄量が低下している時期に 3 例で血清 $\mathrm{Na}$ 上昇を 認めたが，乙れは血清 $\mathrm{Na}$ 值の変動が正常範囲内のものであり，かつ正確な balance study を施行してない とともあり, あまり重要ではないと考觉られた。

Luetscher ら $^{35}$ 亿よれば，実験的に行なつた甲状腺機能の変動によつては尿中 aldosterone 排泄量に影響 はなかつたとしているが，われわれの経験した 3 例でも同様の結果を得た。

重症筋無力症で extremity weakness 考挡めた時期に一致してみられた一過性の secondary hyperaldosteronuria の可能性として次の諸点が考元られる； a ) 本症の原因として筋細胞内電解質の異常を来たす neuromuscular transmission の障害が考えられているとと ${ }^{25}$ ) b) Mineralocorticoid activity の一寸した 変化が臨床的に明らかな筋力低下を起すとと，および本症の筋肉がイオン漲度の微妙な変化に対し異常に反 応すると想像されるとと（筋細胞膜透過性の異常) ${ }^{13)}$ ，ｅ）本症で血清 K 值は正常範囲内のととが多いにか

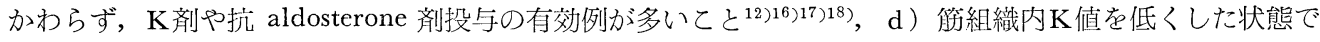
は，aldosterone により細胞内K 值が更に低下するとと， ${ }^{36) ， e ~ ） ~ i n ~ v i t r o ~ て ゙ ~ a l d o s t e r o n e ~ に ~ a c e t y l c h o l i n e ~}$ 拮抗作用があるとと ${ }^{37}$ 等である.

しかるに重症筋無力症中 extremity weakness を有する電揧型および全身型の症例で, extremity weakness を認める時期に一致して，何故一過性に hyperaldosteronuria を来たしたかは尚不明である.

結 語

電撃型 2 例, 全身型 4 例および眼噞型 4 例の重症䈈無力症患者 10 例の尿中 aldosterone 排泄量を臨床経過 を追つて測定した.

電撃型および全身型患者全例で extremity weakness を有する時期に尿中 aldosterone 排泄量が增加して おり, extremity weakness の消失を認め得た 4 例で尿中 aldosterone 排泄量の正常範囲への減少を認めた。 4 例の眼噞型患者では全経過を通して尿中 aldosterone 排泄量は正常であつた.

脍腺摘出術を施行した電撃型 1 例，全身型 2 例および眼臉型 1 例の 4 例の手術前後の尿中 aldosterone 排 泄量には有意の変動は認められなかつた。尚尿中 $\mathrm{Na} / \mathrm{K}$ 比も aldosterone 值と一致して変動したが, 同時 そ測定した尿中 17-KS, 17-OHCS および catecholamine 值は extremity weakness の有無とは無関係で特 別の変動は認められなかつた。

*1) —*6)

薬剤はそれぞれ以下の商品名を使用した。 
*1) Aldosterone $=\Delta^{4}$-pregnen-11 $\beta, 21$-diol-18-al-3,20-dione ;

*2) Tensilon=dimethylethyl (3-hydroxyphenyl) ammonium chloride, (edrophonium chloride) ;

*3) Ambenonium chloride $=\mathrm{N}, \mathrm{N}^{\prime}$-bis (2-diethylaminoethyl) oxamide bis (2-chlorobenzyl) chloride ;

*4) Spironolactone $=3$-(3-oxo-7 $\alpha$-acetylthio-17 $\beta$-hydroxy-4-androsten- $17 \alpha$-yl) propionic acid- $\gamma$-lactone ;

*5) Triamteren $=2,4,7$-triamino-6-phenyl-pteridine ;

*6) Norethynodrel $=17 \alpha$-ethynyl-17 $\beta$-hydroxy-5(10)-estren-3-one.

稿を終るに当り，御指導・御校閲を賜わつた恩仰木村武教授に深く感謝致します。また本研究に対し終 始御援助および测定法の御指導を頂いた本学生化学教室太田稔講沛, および尿中 catecholamine の测定を して頂いた本学木村内科井上一彦助手に感謝致します。

また aldosterone free を心よく提供して下さつたエーザイ製薬， cortisone free および hydrocortisone free を提供頂いた帝国藏器抢よび塩野義製薬各社住謝意を表します。尚本諭文の要旨は第11回日本内分泌 学会東部部会㧍よび第37・38および39回日本内分泌学会総会において発表した。

\section{文献}

1) CONN, J.W. : J. Lab. Clin.Med., $45: 3$, (1955).

2) NEHER, R. \& A. WETTSTEIN : J. Clin. Invest., $35: 800$, (1956). $\quad 3$ 3) HERNANDO, L., J. CRABBE, E. ROSS, W.J. ROSS, W.J. REDDY, A.E. RENOLD, D.H. NELSON \& G.W. THORN : Metabolism, $6: 518$, (1957). 久田昇一：日内分泌誌, $36: 1396,(1960)$.

5) HAINES, W.J. : Recent. Progr. Hormone Res., VII : 255, (1952). 6) GENEST, J. : Canad. Med. Ass., 77 : 780, (1957).

7) NAWACZYNSKI, W., E. KOIW \& J. GENEST : Canad. J. Biochem. Physiol., $35: 425$, (1957). 8) SIMPSON, S.A., J.F. TAIT, A. WETTSTEIN, R. NEHER, J. VON EUW O. SCHINDLER, \& T. REICHSTEN : Helv. Chim. Acta, $37: 1163$, (1954). $\quad$ 9) DREKTER, I.J., A. HEISLER, G.R. SCISM, S. STERN, S. PEARSON \& T.H. McGAVAGK : J. Glin. Endocr., $7: 795$, (1947). 10) PORTER, C.C. \& R.H. SILBER : J. Biol. Chem., $185: 201,(1950)$.

11) EULER, U.S.v. \& I. FLODING : Acta Physiol. Scand., 33(Suppl. 118) : 45, (1955).

12) GOTTLIEB, B. \& L.P.E. LAURENT : Lancet, II : 528, (1961)

13) FRENKEL, M. \& E.N. EHRLIGH : Ann. Intern. Med., 60 :

971, (1961).

14) FRENKEL, M. : Arch. Neurol., $11: 613$, (1964). 内科, $9: 475,(1962)$ (1962). (1962).

18) SATOYOSHI, E, K. MURAKAMI \& T. OKAZAKI : Lancet, $1: 741,(1964)$. 19) AITKIN, R.S. \& E.N. ALLOTT : Clin. Sci., $3: 47$, (1937). DANIELS : Brain, 57 : 91, (1934).

21) CONN, J.W.,

15）冲中重雄ほか：
17) OKINAKA, S.,N. OHSAWA, K. SHIZUME et al., : 20) BIEMOND, A. \& A.P.
LOUIS, S.S. FAJANS, D.H. STREETEN \& R.D. JOHNSON : Lancet, 1 : 802, (1957). 22) ALLOTT, E.N. \& B. MCARDLE : Clin. Sci., $3: 229$, (1948). $\quad$ 23) ROWLEY, P.T. \& B.KLIMAN : Am. J. Med., $18: 376$, (1960). 24) SHY, G.M., T. WANKO, P.T. ROWLEY \& A.G. ENGEL : Exper. Neurol., $3: 53$, (1961). 25) 冲中重雄: 内科臨床と剖検（沖中内科17年のあゆみ）初版 (1963), 112, 南江堂, 東京. 26) HODGKIN, A.L. : Proc. Roy. Soc. B., $148: 1$, (1958). 27) GROB, D., A. LILJESTRAND \& R.J. JOHNS : Am. J. Med., $23: 340$, (1957). 28) GREUTZFELDT, O.D., B.C. ABBOTT, W.M. FOWLER \& G.M. FOWLER \& C.M. PEARSON : EEG \& Clin. Neurophysiol., $15: 508$, (1963). 29) 里吉営二郎ほか：臨床脳波, $5: 136,(1963)$. 30) 里吉営二郎ほか：日臨内 小誌, $16: 1179,(1961)$. 31）里吉営二郎：日本臨床代謝学会記録，II : 59, (1965). 32) 鎮目和夫ほか：日本臨床代謝学会記録, II : 63, (1965).

33) DAHLBÄGK, O., D. ELMQVIST, 
T.R. JOHNS, S. RADNER \& S. THESLEFF : J. Physiol.,156 : 336, (1961).

34) HECHTER, O. \& G. LESTER : Recent. Progr. Hormone Res., $16: 139$, (1960). 35) LUETSGHER, J.A., A.P. COHN, C.A. GAMARGO, A.J. DOWDY \& A.M. GALlAGHAN : J. Clin. Endocr., $23: 873$, (1963). 36) 里吉営二郎：内分泌と代謝， $4: 165 ，(1963)$. $2: 57,(1961)$.

37) GROSS, F. : Experientia, 